\title{
Effect of Cadmium Repartition on Nitrogen Metabolism in Tobacco Seedlings
}

\section{Houda Maaroufi Dguimi ${ }^{*}$, Khulud Alshehri², Chokri Zaghdoud ${ }^{1}$, Ali Khalaf Albaggar², Mohamed Debouba ${ }^{3}$}

${ }^{1}$ Unité de recherche: Nutrition et métabolisme azotés et protéines de stress, Faculté des Sciences de Tunis, Département de Biologie, Université Tunis EL Manar, Tunis, Tunisie

${ }^{2}$ Science and Art Faculty Baljurashi, AL BAHA University, AL Baha, KSA

${ }^{3}$ Institut Supérieur de Biologie Appliquée, Médenine, Route Jorf, Tunisie

Email: ^houda_maaroufi@yahoo.fr

How to cite this paper: Maaroufi Dguimi, H., Alshehri, K., Zaghdoud, C., Albaggar, A.K. and Debouba, M. (2019) Effect of Cadmium Repartition on Nitrogen Metabolism in Tobacco Seedlings. Open Access Library Journal, 6: e4000. https://doi.org/10.4236/oalib.1104000

Received: October 5, 2017

Accepted: March 10, 2019

Published: March 13, 2019

Copyright $\odot 2019$ by authors and Open Access Library Inc.

This work is licensed under the Creative Commons Attribution International License (CC BY 4.0).

http://creativecommons.org/licenses/by/4.0/

\begin{abstract}
Thirty-day-old tobacco seedlings (Nicotiana tabaccum, Bureley v) were subjected during one week to increasing cadmium $(\mathrm{Cd})$ concentrations $(0,10,20$, 50 and $\left.100 \mu \mathrm{M} \mathrm{CdCl}_{2}\right)$. Increasing Cd stress led to a gradual decrease of dry weight (DW) production, water and nitrate contents. More than the half of $\mathrm{Cd}$ accumulated per plant was sequestered in the oldest leaf stage ( $\mathrm{S}_{1}$ leaves). Leaves from $S_{1}$ were the least affected by Cd stress. The activities of nitrate reductase (NR, EC 1.6.1.6), nitrite reductase ( $\mathrm{NiR}, \mathrm{EC}$ 1.7.7.1) were the least reduced in $S_{1}$ leaves despite of the high presence of Cd ions. At $100 \mu \mathrm{M} \mathrm{Cd}$, glutamine synthetase activity (GS, EC 6.3.1.2) from $S_{1}$ leaves rose to become 2 times more important than control. Western Blot analysis showed that $S_{1} G S$ activity induction was correlated to the $\mathrm{GS}_{1}$ and $\mathrm{GS}_{2}$ protein accumulation. Young leaves $\left(\mathrm{S}_{3}\right.$ leaves) were more affected by $\mathrm{Cd}$ stress than old leaves. The GS activity reduction in $S_{3}$ leaves was correlated to $\mathrm{GS}_{2}$ protein decrease detected by western-blot analysis. So, tobacco plant accumulated $\mathrm{Cd}$ ions in old leaves $\left(S_{1}\right.$ leaves) to protect younger leaves which are more sensitive to Cd effects. Leaves from $S_{1}$ are a target organ to verify an eventual soil contamination per cadmium. This leaves may evolve adaptive process to partially inactivate $\mathrm{Cd}$ ions and maintain stable rate of nitrogen metabolism.
\end{abstract}

\section{Subject Areas}

Environmental Sciences

\section{Keywords}

Cadmium, Nitrate Reductase, Glutamate Dehydrogenase, Nitrogen Metabolism 


\section{Introduction}

Cadmium (Cd) is the more noxious soil pollutant and its presence in the environment is essentially due to anthropogenic activities [1]. Because of its long biological half life, $\mathrm{Cd}^{2+}$ which belongs to the group of non-essential transition metals is highly toxic. Contamination of agricultural land, and so edible plants, is essentially due to the application of Cd-containing fertilizers and sewage sludges, atmospheric deposition or geogenic origin of $\mathrm{Cd}$ [2].

Cadmium toxicity is a major factor limiting plant growth in many soils [3]. Cd had many dangerous effects on plants, essentially the reduction of plant growth [3]. Cadmium inhibitor effect on growth could result from photosynthesis rate reduction [4] and the decline in nitrogen metabolism [5] [6] [7] [8]. A great deal of research has established the ability of cadmium to induce reactive oxygen species (ROS) production in plants [1] [9]. Cadmium stress may also impair the plasma membrane integrity by increasing lipid peroxidation [10]. Alternatively, it could alter plasma membrane permeability essentially nitrate and other essential-nutrients uptake. Hyperaccumulators are ideal plant species used for phytoremediation of $\mathrm{Cd}$ contaminated soils. Tobacco plants could be considered too, as a cadmium hyperaccumulator plant [8]. A full understanding of metal tolerance mechanisms of hyperaccumulators will facilitate enhancing their phytoremediation efficiency.

Previous work showed that tobacco plants accumulated $\mathrm{Cd}$ mostly in leaves. Leaf Cd content was six times more important than root Cd content. However, tobacco leaves were less affected by $\mathrm{Cd}$ stress than roots. In this report, we aimed at better understanding the differences in Cd partitioning between roots and different foliar stages to explain how tobacco leaves supported the high Cd level and could protect nitrogen metabolism under stress conditions. To clarify this question, this study investigated the effects of $\mathrm{Cd}$ accumulation on the activity of key enzymes involved in nitrogen metabolism in roots and in different foliar stages of tobacco.

\section{Materials and Methods}

\subsection{Plant Material and Growth Conditions}

Tobacco seeds (Nicotiana tabaccum, Bureley V.) were germinated on a moistured filter paper at $25^{\circ} \mathrm{C}$ in the dark. The uniform seedlings were then transferred to continuously aerated nutrient solutions containing $8 \mathrm{mM} \mathrm{KNO}_{3}, 2 \mathrm{mM}$ $\mathrm{Ca}\left(\mathrm{NO}_{3}\right)_{2}, 1 \mathrm{mM} \mathrm{KH_{2 }} \mathrm{PO}_{4}, 1 \mathrm{mM} \mathrm{MgSO}{ }_{4}, 32.9 \mu \mathrm{M}$ Fe-K-EDTA, and micronutrients: $30 \mu \mathrm{M} \mathrm{H}_{3} \mathrm{BO}_{4}, 5 \mu \mathrm{M} \mathrm{MnSO}_{4}, 1 \mu \mathrm{M} \mathrm{CuSO}_{4}, 1 \mu \mathrm{M} \mathrm{ZnSO}_{4}, 1 \mu \mathrm{M}$ $\left(\mathrm{NH}_{4}\right)_{6} \mathrm{Mo}_{7} \mathrm{O}_{24}$. Plants were grown in a growth chamber with a photoperiod of 16 h-light $\left(\mathrm{m}^{-2} \mathrm{~s}^{-2}\right) / 8 \mathrm{~h}$-darck at $26^{\circ} \mathrm{C}$ and $20^{\circ} \mathrm{C}$, respectively. The relative humidity was maintained with $70 \%$ and $90 \%$ in the light and in dark respectively. After an initial growth period of thirty days, $\mathrm{CdCl}_{2}(10,20,50$ and $100 \mu \mathrm{M})$ was added to the medium. After 7 days of heavy metal treatment, plants were assorted into shoots and roots. Roots were rapidly washed three times in $1 \mathrm{~L}$ of distilled water 
and samples were desiccated at $60^{\circ} \mathrm{C}$. The fresh and dry weights of each sample were determined before chemical analysis. Plant materials were kept at $-80^{\circ} \mathrm{C}$ before analysis.

\subsection{Determination of Nitrate Content}

Nitrate ions were extracted from dry matter with $0.5 \mathrm{~N} \mathrm{H}_{2} \mathrm{SO}_{4}$ at room temperature for $48 \mathrm{~h}$. Nitrate was calorimetrically determined on an automatic analyzer following diazotation of the nitrite obtained by reduction of nitrate on a cadmium column [11].

\subsection{Determination of Cadmium Content}

Cadmium content in various plant tissues was analyzed by digestion of dried samples with an acid mixture $\left(\mathrm{HNO}_{3} / \mathrm{HClO}_{4}, 4 / 1 \mathrm{v} / \mathrm{v}\right)$. Cadmium concentrations were determined by atomic absorption spectrophotometry (Perkin-Elmer, Analyst 300).

\subsection{Protein Content}

Soluble protein content was quantified using Coomassie Brilliant blue [12]. with bovine serum albumin as a protein standard.

\subsection{Sugar Content}

Total soluble sugars were determined according to [13].

\subsection{Enzyme Assays}

\subsubsection{Nitrate Reductase}

Plant material was homogenized with $100 \mathrm{mM}$ potassium phosphate buffer ( $\mathrm{pH}$ 7.4) containing $7.5 \mathrm{mM}$ cystein, $1 \mathrm{mM}$ EDTA and $1.5 \%(\mathrm{w} / \mathrm{v})$ casein. The homogenate was centrifuged at $30,000 \mathrm{~g}$ for $15 \mathrm{~min}$ at $4{ }^{\circ} \mathrm{C}$. Nitrate reductase activity (NRA) was determined according to the method described by [14]. The extract of $0.1 \mathrm{ml}$ was incubated in a reaction mixture containing $0.5 \mathrm{ml}$ of $100 \mathrm{mM}$ potassium phosphate buffer ( $\mathrm{pH} 7.4$ ), $0.1 \mathrm{ml}$ of $0.15 \mathrm{mM} \mathrm{NADH}$, and $0.1 \mathrm{ml}$ of $100 \mathrm{mM} \mathrm{KNO}$ at $30^{\circ} \mathrm{C}$ for $30 \mathrm{~min}$. The extract was incubated with $10 \mathrm{mM}$ $\mathrm{MgCl}_{2}$ (for actual NRA determination) or with $15 \mathrm{mM}$ EDTA (for maximum NRA determination). The reaction was stopped by $0.2 \mathrm{ml}$ of $1000 \mathrm{mM}$ zinc acetate. Nitrite ions were assayed after diazotation with $1 \mathrm{ml}$ of $5.8 \mathrm{mM}$ sulfanilamide, $1.5 \mathrm{~N} \mathrm{HCl}$, and $1 \mathrm{ml}$ of $0.8 \mathrm{mM} \mathrm{N}$-naphthyl-ethylene-diamine-dichloride.

\subsubsection{Nitrite Reductase}

Enzyme extracts were prepared as described above for nitrate reductase. Nitrite reductase was assayed by the method of [15]. The extract of $0.1 \mathrm{~mL}$ was incubated in a solution containing $0.4 \mathrm{~mL}$ of $100 \mathrm{mM}$ potassium phosphate buffer ( $\mathrm{pH}$ 7.4), $0.1 \mathrm{~mL}$ of $15 \mathrm{mM}$ sodium nitrite, $0.2 \mathrm{~mL}$ of $5 \mathrm{mM}$ methyl viologen, 0.2 $\mathrm{mL}$ of $86.2 \mathrm{mM}$ sodium dithionite in a $190 \mathrm{mM} \mathrm{NaHCO}_{3}$. The reaction was stopped by a violent agitation on vortex. Nitrite ions were assayed as described 
for NRA assay.

\subsubsection{Glutamine Synthetase}

Samples were homogenized with grinding medium containing $25 \mathrm{mM}$ Tris- $\mathrm{HCl}$ buffer (pH 7.6), $1 \mathrm{mM} \mathrm{MgCl}$, 1 mM EDTA, $14 \mathrm{mM} \beta$-mercaptoethanol and $1 \%$ $(\mathrm{w} / \mathrm{v})$ polyvinylpyrrolidone (PVP). The homogenate was centrifuged at 25,000 $\mathrm{g}$ for $30 \mathrm{~min}$ at $4^{\circ} \mathrm{C}$. GS activity was determined using hydroxylamine as substrate, and the formation of $\gamma$-glutamylhydroxamate $(\gamma$-GHM) was quantified with acidified ferric chloride [16].

\subsubsection{Glutamate Dehydrogenase}

GDH extraction was performed according to the method described by [17]. Frozen samples were homogenized in a cold mortar and pestle with $100 \mathrm{mM}$ Tris-HCl ( $\mathrm{pH}$ 7.5), $14 \mathrm{mM}$ 2-mercaptoethanol, and 1\% (w/v) PVP. The extract was centrifuged at $12,000 \mathrm{~g}$ for $15 \mathrm{~min}$ at $4^{\circ} \mathrm{C}$. GDH activity was determined by following the absorbance changes at $340 \mathrm{~nm}$.

\subsection{Western-Blot Analyses}

Proteins were extracted from frozen leaf material in cold extraction buffer containing $50 \mathrm{mM}$ Tris- $\mathrm{HCl} \mathrm{pH}$ 7.5, $1 \mathrm{mM}$ EDTA, $1 \mathrm{mM} \mathrm{MgCl}$, PVP 0.5\% (w/v), 2 mercaptoethanol $0.1 \%(\mathrm{v} / \mathrm{v})$ and $4 \mathrm{mM}$ leupeptine and separated by SDS-PAGE [18] Equal amounts of protein $(25 \mu \mathrm{g})$ were loaded in each track. The percentage of polyacrylamide in the running gels was $12 \%$. Proteins were electrophoretically transferred to nitrocellulose membranes for Western blot analysis. Polypeptide detection was done using polyclonal antiserum raised against Arabidopsis GS (Masclaux-Daubresse). Antibodies were raised in rabbits against the synthetic peptide AYGEGNERRLTG by Eurogentec (Seraing, Belgium) and they detected both $\mathrm{GS}_{1}$ and $\mathrm{GS}_{2}$ isoenzymes.

\subsection{Statistical Analysis}

The data are presented in the figures and in the tables as the average of at least six replicates per treatment and means \pm confidence limits at $\mathrm{P}=0.05$ level. Each experiment was conducted in duplicate.

\section{Results}

\subsection{Growth Response to Cadmium}

Cadmium treatment induced a progressive decrease of leaf and root dry weight (DW) production (Figure $1(\mathrm{a}))$. Since low Cd treatment $(10 \mu \mathrm{M})$, the root and leaf growth was affected. At high Cd treatment $(100 \mu \mathrm{M})$, the reduction of root DW production was more than $70 \%$. For the different foliar stages, the growth reduction was $36 \%, 64 \%$ and $76 \%$ in $S_{1}, S_{2}$ and $S_{3}$, respectively. $S_{1}$ was the oldest foliar stage, $S_{2}$ and $S_{3}$ were younger than $S_{1}$ (Figure $1(a)$ ). Cd belated the emergence of the fourth foliar stage in plants treated by high Cd doses (50 and 100 $\mu \mathrm{M})$. 
(a)

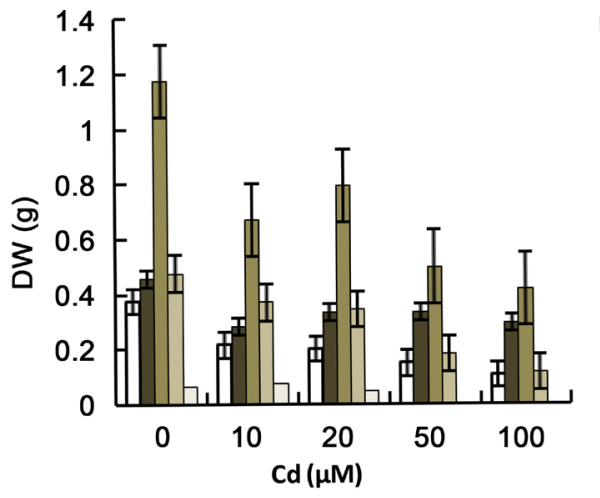

$\square \mathrm{R}$

$\square \mathrm{S}_{1}$

$\square S_{2}$

$\square S_{3}$

$\square \mathrm{S}_{4}$

(b) $307 \quad \square R$
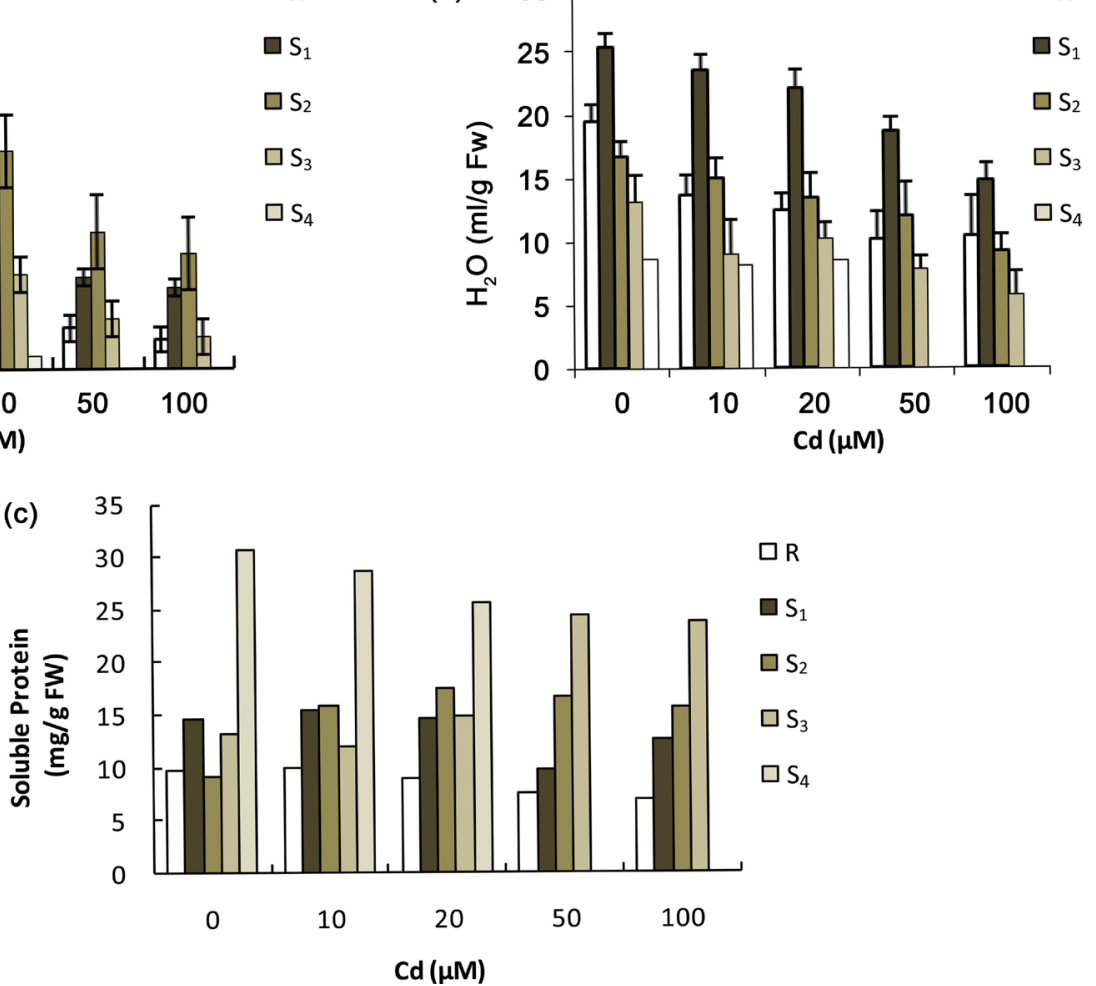

Figure 1. Effects of Cd treatments $(0,10,20,50100 \mu \mathrm{M})$ for 7 days on (a) dry weight production (DW), (b) water contents and (c) Soluble protein contents. Data are means of six replicates \pm CL at 0.05 levels.

The growth inhibition of tobacco seedlings was accompanied by a decrease in water contents (Figure 1(b)). At $100 \mu \mathrm{M} \mathrm{Cd}$, root water content was decreased by about $45 \%$. The leaf hydration was significantly reduced: Old leaves $\left(\mathrm{S}_{1}\right)$ were less dehydrated than $S_{3}$ leaves. The decrease of $S_{1}, S_{2}$ and $S_{3}$ water content was respectively about $40 \%, 45 \%$ and $57 \%$ (Figure 1 (b)).

Soluble protein (SP) contents were gradually decreased with $\mathrm{Cd}$ treatment (Figure $1(\mathrm{c})$ ). The highest Cd stress $(100 \mu \mathrm{M})$ resulted in a decrease in soluble protein contents in roots $(20 \%)$ and in leaves. The decrease of SP content was more important in $\mathrm{S}_{1}$ leaves (50\%) and lesser in $\mathrm{S}_{3}$ and $\mathrm{S}_{2}$ leaves (25\%).

\section{2. $\mathrm{NO}_{3}^{-}, \mathrm{Cd}$ and Soluble Sugar Contents}

In control plants, more than $85 \%$ of total $\mathrm{NO}_{3}^{-}$ions were accumulated in leaves (Figure 2(a)). Under increasing $\mathrm{Cd}$ concentration, $\mathrm{NO}_{3}^{-}$contents were greatly decreased in both leaves and roots. At $100 \mu \mathrm{M} \mathrm{Cd}$, the decrease of root $\mathrm{NO}_{3}^{-}$ content was $80 \%$ with respect to control. In leaves, the reduction of $\mathrm{NO}_{3}^{-}$content was, respectively, $60 \%, 90 \%$ and $95 \%$ in $\mathrm{S}_{1}, \mathrm{~S}_{2}$ and $\mathrm{S}_{3}$ leaves. The $\mathrm{NO}_{3}^{-}$content of $S_{1}$ leaves was the less reduced under high Cd stress (Figure 2(a)).

Cadmium ions were more accumulated in leaves than in roots. At $10 \mu \mathrm{M} \mathrm{Cd}$, the leaves accumulated more than $90 \%$ of the total of cadmium absorbed by plant (Figure $2(\mathrm{~b})$ ). In leaves, $\mathrm{S}_{1}$ accumulated $50 \%$ of the total Cd quantity accumulated per plant. $\mathrm{S}_{2}$ and $\mathrm{S}_{3}$ accumulated respectively $30 \%$ and $3 \%$ of the total 


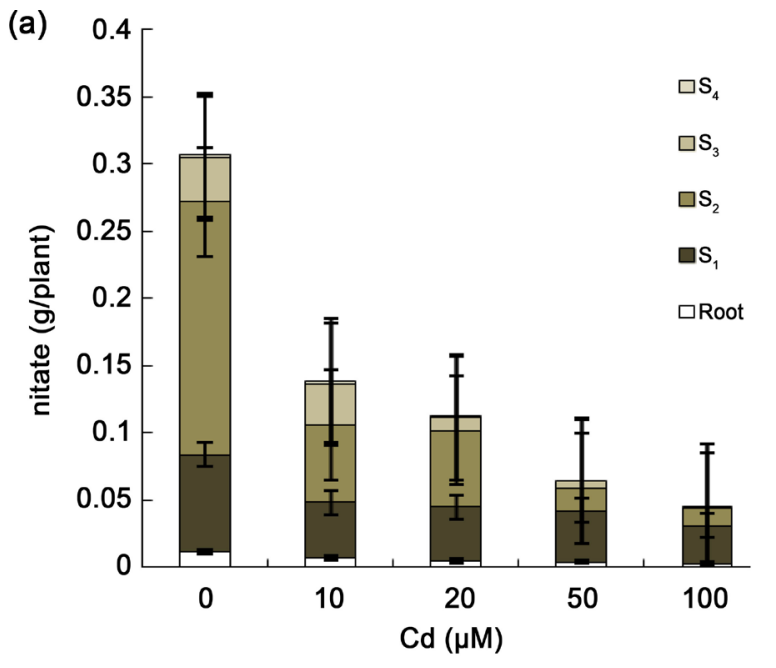

(b)

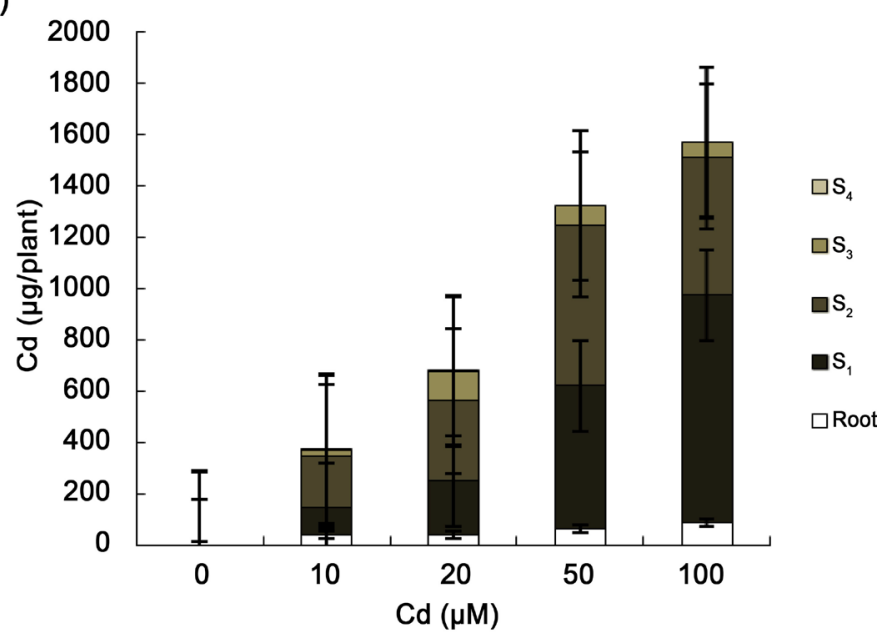

(c)

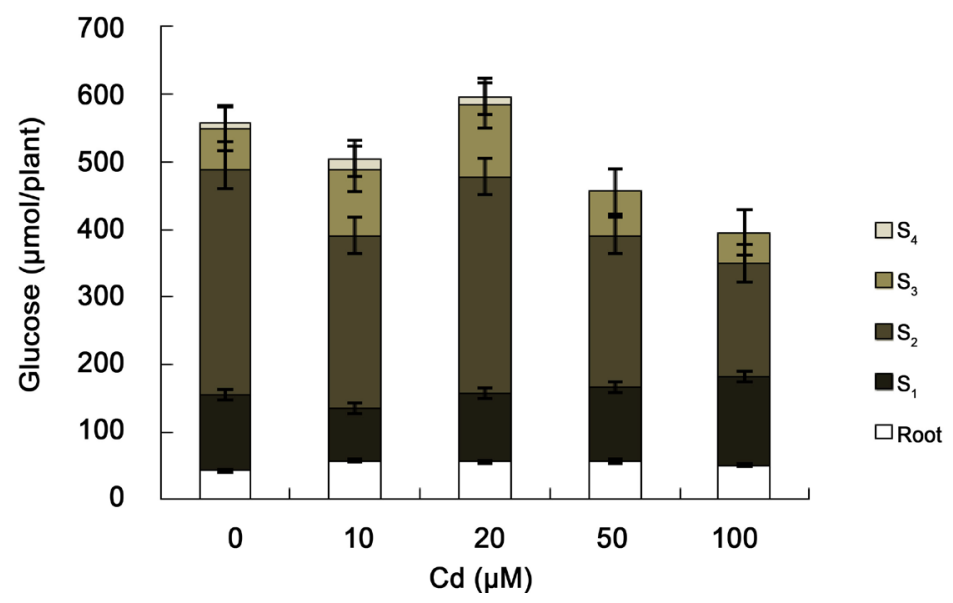

Figure 2. Changes in contents of (a) $\mathrm{NO}_{3}^{-}$(g/plant), (b) Cd (g/plant) and (c) soluble sugars ( $\mu$ mol/plant) in different part of plants under Cd treatments $(0,10,20,50,100 \mu \mathrm{M})$ for 7 days. Data are means of six replicates $\pm \mathrm{CL}$ at 0.05 levels

quantity of Cd accumulated in each plant (Figure 2(b)).

In control tobacco seedlings, the major quantity of soluble sugars was accumulated in leaves: $80 \%$ of the total sugar quantity accumulated per plant. Roots accumulated $6 \%$ of the whole sugar quantity accumulated per plant. Under Cd stress, the soluble sugar quantity increased in roots $(+20 \%)$ and in $S_{1}$ leaves $(+15 \%)$. The soluble sugar quantity decreased apparently in $S_{2}(50 \%)$ and in $S_{3}$ $(25 \%)$ leaves (Figure $2(\mathrm{c})$ ).

\subsection{Effects of $\mathrm{CdCl}_{2}$ on the Nitrogen-Assimilating Enzymes}

\subsubsection{Nitrate Reductase Activity}

In control tobacco seedlings, Nitrate reductase (NR) activity was higher in the leaves $(80 \%)$ than in the roots (Figure 3(a)). Under high Cd treatment, root NR activity decreased with $80 \%$ with respect to control. In leaves, the reduction of NR activity was respectively $56 \%, 60 \%$ and $40 \%$ in $S_{1}, S_{2}$ and $S_{3}$. The NR activity reduction was more severe in roots. At $100 \mu \mathrm{M}$ Cd treatment, root NR activity did not exceed 1, $8 \%$ of the whole NR activity for each plant (Figure 3(a)). 


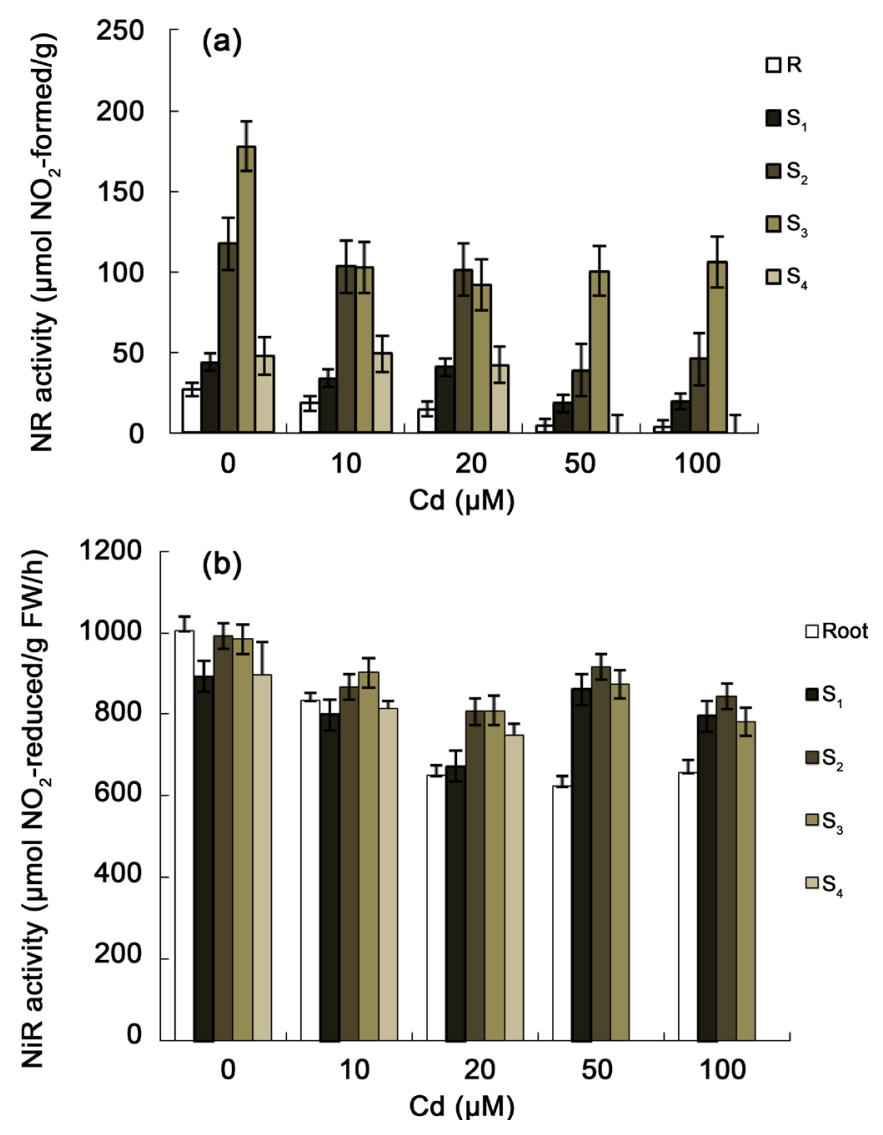

Figure 3. Effects of Cd treatments $(0,10,20,50,100 \mu \mathrm{M})$ for 7 days on (a) Nitrate reductase activity ( $\mu \mathrm{mol} \mathrm{NO}_{2}^{-}$formed. $\mathrm{g}^{-1} \mathrm{FWh}^{-1}$ ), and (b) Nitrite reductase activity ( $\mu \mathrm{mol}$ $\mathrm{NO}_{2}^{-}$reduced. $\mathrm{g}^{-1} \mathrm{FWh}^{-1}$ ) in different organs. Data are means of six replicates $\pm \mathrm{CL}$ at 0.05 levels

\subsubsection{Nitrite Reductase Activity}

In leaves of control seedlings, $\mathrm{NiR}$ activity was more important than in roots; it represented $70 \%$ of the whole NiR activity in each plant. The NiR activity in roots was $18 \%$ of the total NiR activity per plant. The Cd addition in the culture medium caused a decrease of NiR activity in each plant organ. At $100 \mu \mathrm{M}$ treatment, root NiR activity was more affected; it was decreased by about $35 \%$. In leaves, the reduction of $S_{1}, S_{2}$ and $S_{3} N i R$ activity were correspondingly, $11 \%$, $15 \%$ and $20 \%$ with respect to control (Figure $3(\mathrm{~b})$ ). $\mathrm{S}_{1} \mathrm{NiR}$ activity was less affected by high Cd treatment.

\subsubsection{Glutamine Synthetase Activity}

In the control plants, more than $80 \%$ of total GS activity was restricted in leaves. The inhibitory effect of Cd on GS activity appeared in each plant organ except for $S_{1}$ GS activity. At $100 \mu \mathrm{M}$, GS activity decreased by $40 \%$ in roots with respect to control. Leaves from $S_{1}$ GS activity increased to become 2 times more important than control. Leaves from $\mathrm{S}_{3}$ GS activity decreased by $60 \%$ with respect to the control (Figure 4(a)). Whereas, leaves from $S_{2}$ GS activity was even under high Cd treatment. Western blot analysis showed that $\mathrm{GS}_{2}$ is the major isoen- 

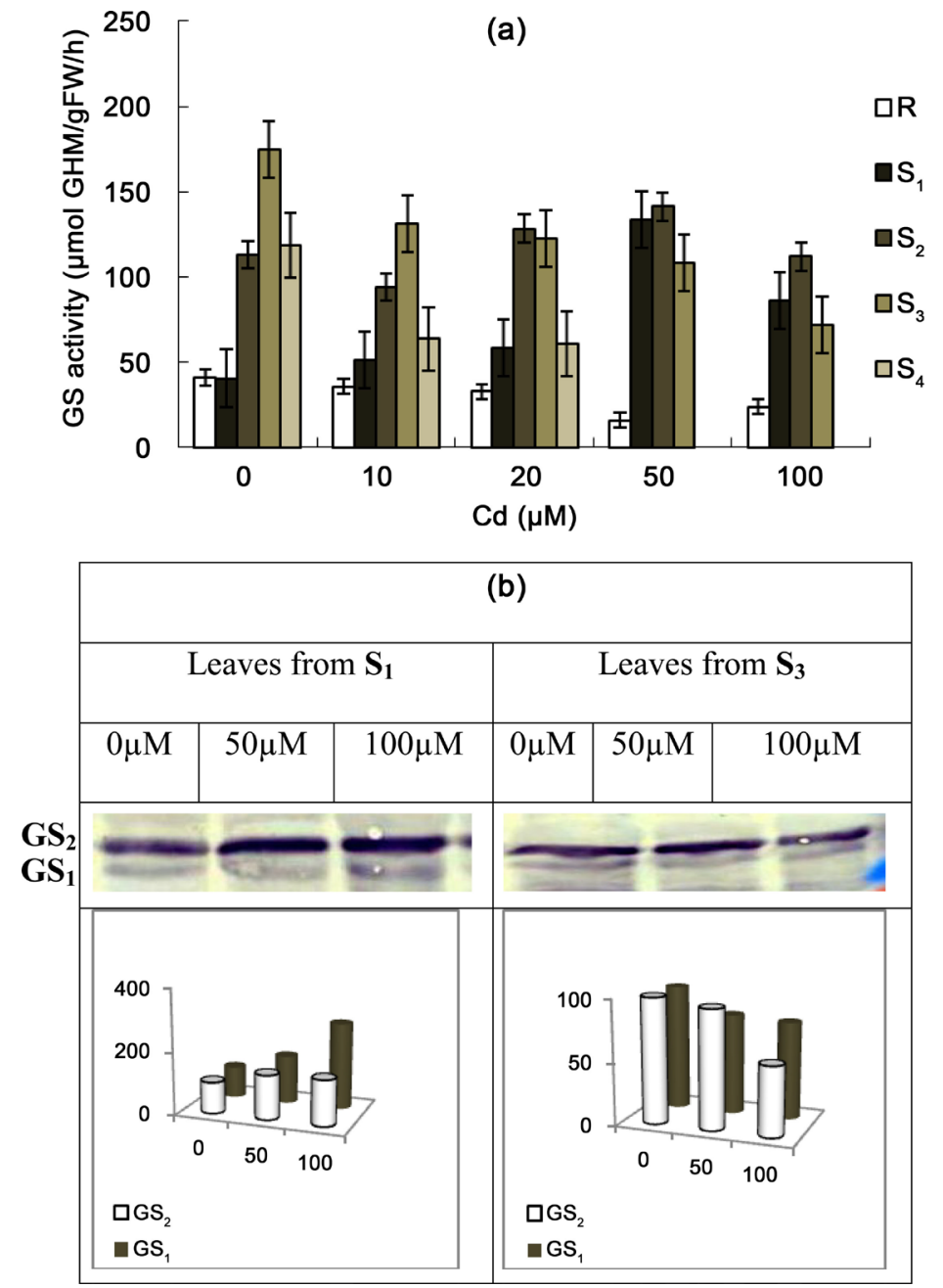

Figure 4. Effects of Cd treatments $(0,10,20,50,100 \mu \mathrm{M})$ for 7 days on (a) GS activity ( $\mu$ mol $\gamma$-glutamyl hydroxamate. $\mathrm{g}^{-1} \mathrm{FW} \mathrm{h}^{-1}$ ) in different foliar stages and roots. Data are means of six replicates $\pm C L$ at 0.05 levels. (b)Western-Blot analysis is assayed from $S_{1}$ and $\mathrm{S}_{3}$ leaves in response to 7 days of 0,50 and $100 \mu \mathrm{M}$ Cd grown on hydroponic medium. Total proteins are extracted from the seedlings as described in "Materials and Methods". An aliquot of $25 \mu \mathrm{g}$ of total protein from each sample was loaded onto each line: in Control leaves (CL), stressed leaves (SL).

zyme in tobacco leaves. Cadmium treatment reduced $\mathrm{GS}_{1}$ and $\mathrm{GS}_{2}$ protein quantity in $S_{3}$ leaves. The reduction of GS protein quantity is correlated to the decrease of GS activity. This reduction may be the result of protein degradation. Cadmium could have inhibitory effect on GS expression. Cadmium stress induced $\mathrm{GS}_{1}$ and $\mathrm{GS}_{2}$ protein quantity in leaves from $\mathrm{S}_{1}$ (Figure $4(\mathrm{~b})$ ). So, the stimulation of GS activity corresponded to GS protein accumulation.

\subsubsection{Aminating and Deaminating GDH Activities}

In control plants, GDH aminating activity (NADH-GDH) was more important in roots than in leaves (Figure 5(a)). In both organs, aminating GDH activity was more important than deaminating GDH activity (NAD-GDH) (Figure 5(b)). Under Cd treatments, the aminating GDH activity was enhanced in the 

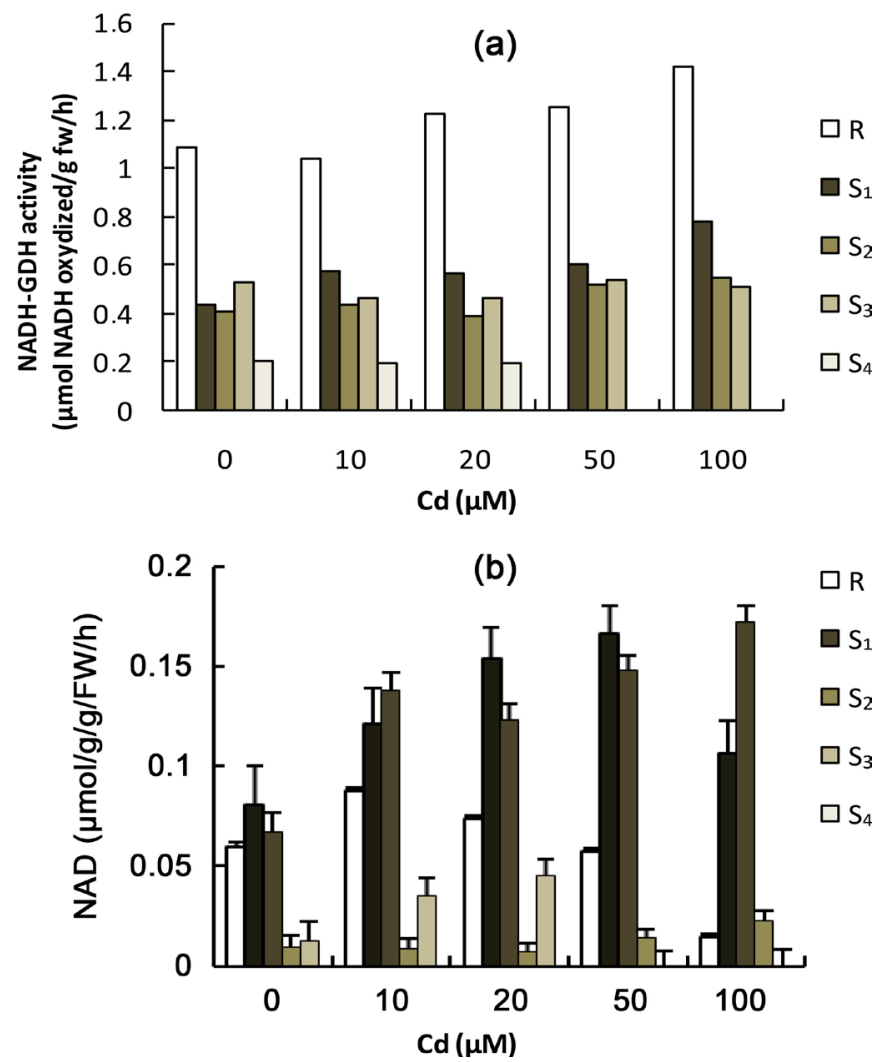

Figure 5. Effects of Cd treatments $(0,10,20,50,100 \mu \mathrm{M})$ for 7 days on (a) NADH-GDH activity ( $\mu \mathrm{mol}$ NADH oxidized. $\mathrm{g}^{-1} \mathrm{FWh}^{-1}$ ) and (b) NAD-GDH activity ( $\mu \mathrm{mol}$ NAD reduced. $\mathrm{g}^{-1} \mathrm{FWh}^{-1}$ ) in different foliar stages and roots. Data are means of six replicates $\pm \mathrm{CL}$ at 0.05 levels.

roots and especially in leaves (Figure 5(a)). At $100 \mu \mathrm{M} \mathrm{Cd}$, the aminating GDH activity was stimulated by $30 \%$ in the roots and more than $70 \%$ in $\mathrm{S}_{1}$ leaves, with respect to controls (Figure 5(a)). Cd stress induced a slight decrease in aminating GDH activity of young leaves $\left(\mathrm{S}_{3}\right.$ and $\left.\mathrm{S}_{4}\right)$. In stressed seedlings, GDH deaminating activity (NAD-GDH) was stimulated in leaves. At high Cd treatment, NAD-GDH activity in young leaves $\left(S_{2}, S_{3}\right.$ and $\left.S_{4}\right)$ was at least two times higher than controls. In the roots, Cd stress had an inhibitory effect on the deaminating $\mathrm{GDH}$ activity which was decreased by $70 \%$ at $100 \mu \mathrm{M} \mathrm{Cd}$ treatment (Figure $5(b)$ ). Cd stress caused a slight increase in deaminating GDH activity in $\mathrm{S}_{1}$ leaves (3\%) with respect to control.

\section{Discussion}

Under increasing Cd treatments, we observed a mean biomass decrease in leaves and in roots [19]. This effect was mainly observed in the roots (70\%), while leaves were apparently damaged only by the highest $\mathrm{Cd}$ concentrations. At 100 $\mu \mathrm{M}$ Cd treatment, the reduction of DW production in leaves from $S_{1}$ (oldest foliar stage) was less important than the decrease in leaves from $S_{2}$ and $S_{3}$. As well, old leaves $\left(\mathrm{S}_{1}\right)$ were, less dehydrated than younger leaves $\left(\mathrm{S}_{3}\right)$ (Figure $1(\mathrm{~b})$ ). So, old leaves from $S_{1}$ were less affected by Cd than younger leaves $\left(S_{2}\right.$ and $\left.S_{3}\right)$. 
Ion analysis showed that $\mathrm{Cd}$ stress led to an elevated decrease in $\mathrm{NO}_{3}^{-}$contents in roots and leaves. The inhibitory effect of $\mathrm{Cd}$ on nitrate contents was reported in tomato seedlings [6] in Solanum nigrum L. [7] and in rice (Huang and Xiong, 2009). The $\mathrm{NO}_{3}^{-}$content decrease was more important in young leaves and roots. Our data showed that $\mathrm{Cd}$ content in leaves and roots did not follow the same trends according to $\mathrm{Cd}$ exposure in the same variety of tobacco (Bureley) which had been reported in Bovet et al. (2006) [19]. Cadmium was accumulated essentially in leaves: at $100 \mu \mathrm{M}$ treatment, leaves had $90 \%$ of $\mathrm{Cd}$ accumulated per plant [8] [20]. This data confirm what had been described by [21] [22]. At high Cd treatment, leaves from $S_{1}$ accumulated more than the half of current Cd per plant, while $S_{3}$ accumulated only $3 \%$. Tobacco plant could adopt exclusive strategy of $\mathrm{Cd}$ ions to protect young leaves from $\mathrm{Cd}$ accumulation. These old leaves that accumulated the most important quantity of $\mathrm{Cd}$ were less affected by Cd stress compared to different foliar stages of tobacco plant (Figure 1(a); Figure 2(a) and Figure 2(b)).

The obtained decrease in nitrate contents in leaves and roots, could affect the subsequent processes involved in nitrate reduction and assimilation. In fact, $\mathrm{NO}_{3}^{-}$regulated the $\mathrm{NR}$ and $\mathrm{NiR}$ expressions [7] and activities [23]. In tobacco seedlings, leaf NR activity was more important than root NR activity (Figure $3(a)$ ). This elevated nitrate reduction was related to the higher leaf NR protein contents [24] and a sufficient availability of light and reducing power [25].

After Cd exposure of tobacco seedlings, NR activity induced a significant decrease [8] [23] which was more pronounced in the roots than in leaves (Figure $3(a))$. In leaves, NR activity reduction was more pronounced in $S_{2}$ leaves. The $\mathrm{NR}$ activity decrease in leaves from $\mathrm{S}_{2}$ was associated to a severe decrease in nitrate content (Figure 2(b)). The nitrate content plays a direct role for NR protein production and activation. Soluble sugar content decreased visibly in leaves from $\mathrm{S}_{2}$ under Cd stress. This reduction of sugar content could cause NR activity decrease in $\mathrm{S}_{2}$ leaves. Klein et al. 2000 [26] reported that low sugar repressed NR gene expression that affected NR protein quantity and NR activity [20]. Thereafter, the Cd-induced inhibition of NR activity in the leaves may result from the low nitrate availability at the enzyme reduction site. The decrease of NR activity in Cd-treated plants could also reflect an increase in the enzyme breakdown induced by toxic oxygen species generated during stress treatment. Indeed free radicals could cause the breakdown of proteins directly by oxidative reaction or indirectly by increasing proteolytic activity. The NiR activity was less affected by Cd stress than the NR activity. This higher NiR activity in the leaves and the roots, disable the toxic accumulation of nitrite ions [27].

With increasing Cd concentration, NiR activity was slightly decreased in the leaves and mainly in the roots (Figure 3(b)). The ammonium produced by NiR was then incorporated into an organic form primarily by the GS enzyme. The presence of $\mathrm{Cd}$ in the nutrient solution caused a significant decrease in GS activity in roots (Figure 4(a)). At $100 \mu \mathrm{M}$ Cd treatment, GS activity increased in $S_{1}$ leaves, to become 2 times more important than control. 
GS activity induction is correlated to the stimulation of $\mathrm{GS}_{1}$ and $\mathrm{GS}_{2}$ protein accumulation (Figure 4(b)). This result was reported previously in tomato seedlings [7]. The GS activity induction and the cytosolic GS isoforme $\left(\mathrm{GS}_{1}\right)$ protein increase were probably related to the induction of GLN transcripts. While in $\mathrm{S}_{3}$ leaves, cadmium treatment reduced $\mathrm{GS}_{1}$ and $\mathrm{GS}_{2}$ protein quantity. The reduction of GS protein quantity is correlated to GS activity decrease. Cadmium stress affected the nitrogen enzyme activity by enzyme protein alterations.

At the same time as, Cd stress was found to increase the aminating GDH activity in $\mathrm{S}_{1}$ leaves and roots, even at high Cd concentrations $(100 \mu \mathrm{M})$ (Figure 5(a)). Conformingly to the increase in $\mathrm{S}_{1}$ GS activity, aminating GDH activity was stimulated to provide GS activity with Glutamate. This increase of aminating GDH was reported by many authors [7]. Aminating GDH activity seems to be also involved in the ammonium detoxification under stress conditions [9].

$\mathrm{Cd}$ stress caused a clear increase in deaminating GDH (NAD-GDH) activity in young leaves. Deaminating GDH activity became 2 times more important than control. This increase in deaminating GDH activity could provide young leaves with carbohydrates. While an important deaminating GDH activity decrease was noted in roots $(70 \%)$. In $\mathrm{S}_{1}$ leaves, the NAD-GDH activity reduction was insignificant (3\%) with respect to control (Figure 5(b)).

We noted that $\mathrm{Cd}$ was accumulated in a lessening gradient from basal to apical leaves. This lessening gradient of $\mathrm{Cd}$ accumulation was accompanied with a $\mathrm{Cd}$ tolerance gradient in the same direction. Thus the response difference of tobacco leaves to the cadmium could be bound either to the leaf mature or/and the contact with important $\mathrm{Cd}$ quantities. Although, more work is needed at the molecular level for further information towards the subcellular accumulation of $\mathrm{Cd}$ in young and old leaves, phytochelatins accumulation and the $\mathrm{Cd}$ effects on protein and gene expression of nitrogen metabolism enzymes. Although foliar $\mathrm{Cd}$ accumulation, roots were more affected by $\mathrm{Cd}$ stress. The lower sensitivity of $S_{1}$ leaves to Cd could be related, at least in part, to a lesser reduction of nitrate reduction and ammonium assimilation, concomitantly with a high increase in aminating GDH activity under $\mathrm{Cd}$ stress and an ability of $\mathrm{S}_{1}$ leaves to accumulate this metal in non-active form. Tobacco plant could be considered as a hyperaccumulator plant used to clean up soil contaminated with cadmium. Ultimately, the large accumulation of $\mathrm{Cd}$ in leaves invited tobacco manufactories using leaves for cigarette production, to strictly make sure that exploited soils are not contaminated by $\mathrm{Cd}$ or other heavy metals. The reduction of cadmium content can reduce health hazards to smokers by selection of young leaves rather than old leaves and control of $\mathrm{pH}$ soil that have an effect on Cd uptake. $\mathrm{S}_{1}$ leaves are a target organ to verify an eventual soil contamination per cadmium.

\section{References}

[1] Di Toppi, L. and Gabbrielli, R. (1999) Response to Cadmium in Higher Plants. Environmental and Experimental Botany, 41, 105-130.

https://doi.org/10.1016/S0098-8472(98)00058-6 
[2] McLaughlin, M.J. and Singh, B.R. (1999) Cadmium in Soils and Plants. Kluwer Academic Publishers, Dordrecht, 1-9. https://doi.org/10.1007/978-94-011-4473-5

[3] Fediuc, E. and Erdei, L. (2002) Physiological and Biochemical Aspects of Cadmium Toxicity and Protective Mechanisms Induced in Phragmites australis and Typha latifolia. Journal of Plant Physiology, 159, 265-271.

https://doi.org/10.1078/0176-1617-00639

[4] Wagner, G.J. and Trotter, M.M. (1982) Inducible Cadmium Binding Complexes of Cabbage and Tobacco. Plant Physiology, 69, 804-809. https://doi.org/10.1104/pp.69.4.804

[5] Wahid, A., Ghani, A., Ali, I. and Ashraf, M.Y. (2007) Effects of Cadmium on Carbon and Nitrogen Assimilation in Shoots of Mungbean [ Vigna radiata (L.) Wilczek Seedlings. Journal of Agronomy \& Crop Science, 193, 357-365.

https://doi.org/10.1111/j.1439-037X.2007.00270.x

[6] Chaffei, C., Pageau, K., Suzuki, A., Gouia, H., Ghorbel, M.H. and Masclaux-Daubresse, C. (2004) Cadmium Toxicity Induced Changes in Nitrogen Management in Lycopersicon esculentum Leading to a Metabolic Safeguard through an Amino Acid Storage Strategy. Plant Cell Physiology, 45, 1681-1693.

https://doi.org/10.1093/pcp/pch192

[7] Wang, L., Zhou, Q., Ding, L. and Sun, Y. (2008) Effect of Cadmium Toxicity on Nitrogen Metabolism in Leaves of Solanum nigrum L. as a Newly Found Cadmium Hyperaccumulator. Journal of Hazardous Materials, 154, 818-825. https://doi.org/10.1016/j.jhazmat.2007.10.097

[8] Mâaroufi, H., Debouba, M., Ghorbel, M.H. and Gouia, H. (2009) Tissue-Specific Cadmium Accumulation and Its Effects on Nitrogen Metabolism in Tobacco (Nicotiana tabaccum, Bureley v. Fb9). Comptes Rendue de Biologie, 332, 58-68. https://doi.org/10.1016/j.crvi.2008.08.021

[9] Romero-Puertas, M.C., McCarthy, I., Gómez, M., Sandalio, L.M., Corpas, F.J., del Río, L.A. and Palma, J.M. (2004) Reactive Oxygen Species-Mediated Enzymatic Systems Involved in the Oxidative Action of 2,4-Dichlorophenoxyacetic Acid. Plant, Cell \& Environment, 27, 1135-1148. https://doi.org/10.1111/j.1365-3040.2004.01219.x

[10] Mediouni, C., Benzarti, O., Tray, B., Ghorbel, M.H. and Jemal, F. (2006) Cadmium and Copper Toxicity for Tomato Seedlings. Agronomy for Sustainable Development, 26, 227-232. https://doi.org/10.1051/agro:2006008

[11] Henriksen, A. and Selmer-Olsen, A.R. (1970) Automatic Methods for Determining Nitrate and Nitrite in Water and Soil Extracts. Analyst, 95, 514-518. https://doi.org/10.1039/an9709500514

[12] Bradford, M.M. (1976) A Rapid and Sensitive Method for the Quantitative Determination of Microgram Quantities of Protein Utilizing the Principle of Protein-Dye Binding. Analytical Biochemistry, 72, 248-254. https://doi.org/10.1016/0003-2697(76)90527-3

[13] Dubois, M., Gilles, K.A., Hamilton, J.K., Rebers, P.A. and Smith, F. (1956) Colorimetric Method for Determination of Sugars and Related Substances. Analytic Chemistry, 28, 350-356. https://doi.org/10.1021/ac60111a017

[14] Robin, P. (1979) Etude de quelques conditions d'extraction du nitrate réductase des racines et des feuilles de plantules de maïs. Physiologie Végétale, 17, 45-54.

[15] Losada, M. and Paneque, A. (1971) Nitrite Reductase. Methods in Enzymology, 23, 487-491. https://doi.org/10.1016/S0076-6879(71)23120-7

[16] Wallsgrove, R.M., Lea, P.J. and Miflin, B.J. (1979) Distribution of the Enzymes of 
Nitrogen Assimilation within the Pea Leaf Cell. Plant Physiology, 63, 232-236. https://doi.org/10.1104/pp.63.2.232

[17] Magalhaes, J.R. and Huber, D.M. (1991) Free Ammonia, Free Amino Acid and Enzyme Activity in Maize Tissue Treated with Methionine sulfoximine. Journal of Plant Nutrition, 14, 883-895. https://doi.org/10.1080/01904169109364249

[18] Laemmli, U.K. (1970) Cleavage of Structural Proteins during the Assembly of the Head of Bacteriophage T4. Nature, 227, 680-685. https://doi.org/10.1038/227680a0

[19] Bovet, L., Rossi, L. and Lugon-Moulin, N.C. (2006) Cadmium Partitioning and Gene Expression Studies in Nicotiana tabacum and Nicotiana rustica. Physiologia Plantarum, 128, 466-475. https://doi.org/10.1111/j.1399-3054.2006.00756.x

[20] Wang, R., Guegler, K., LaBrie, S.T. and Crawford, N.M. (2000) Genomic Analysis of Nutrient Response in Arabidopsis Reveals Diverse Expression Patterns and Novel Metabolic and Potential Regulatory Genes Induced by Nitrate. The Plant Cell, 12, 1491-1510. https://doi.org/10.1105/tpc.12.8.1491

[21] Huang, H. and Xiong, Z.T. (2009) Toxic Effects of Cadmium, Acetochlor and Bensulfuron-Methyl on Nitrogen Metabolism and Plant Growth in Rice Seedlings. Pesticide Biochemistry and Physiology, 94, 64-67. https://doi.org/10.1016/j.pestbp.2009.04.003

[22] Lugon-Moulin, N., Zhang, M., Gadani, F., Rossi, L., Koller, D., Krauss, M. and Wagner, G.J. (2004) Critical Review of the Science and Options for Reducing Cadmium in Tobacco (Nicotiana tabacum L.) and Other Plants. Advances in Agrono$m y, 83,111-180$. https://doi.org/10.1016/S0065-2113(04)83003-7

[23] Takabayashi, M., Wilkerson, F.P. and Robertson, D. (2005) Response of Glutamine Synthetase Gene Transcription and Enzyme Activity to External Nitrogen Sources in the Diatom Skeletonema costatum (Baillariophyceae). Journal of Phycology, 41, 84-94. https://doi.org/10.1111/j.1529-8817.2005.04115.x

[24] Abd-ElBaki, G.K., Siefritz, F., Man, H.M., Weiner, H., Haldenhoff, R. and Kaiser, W. (2000) Nitrate Reductase in Zea mays L. under Salinity. Plant, Cell and Environment, 23, 515-521. https://doi.org/10.1046/j.1365-3040.2000.00568.x

[25] Lillo, C., Meyer, C., Lea, U.S., Provan, F. and Olteda, S. (2004) Mechanism and Importance of Post-Translational Regulation of Nitrate Reductase. Journal of Experimental Botany, 55, 1275-1282. https://doi.org/10.1093/jxb/erh132

[26] Klein, D., Morcuende, R., Stitt, M. and Krapp, A. (2000) Regulation of Nitrate Reductase Expression in Leaves by Nitrate and Nitrogen Metabolism Is Completely Overridden When Sugars Fell below a Critical Level. Plant, Cell and Environment, 23, 863-871. https://doi.org/10.1046/j.1365-3040.2000.00593.x

[27] Ezzine, M. and Ghorbel, M.H. (2006) Physiological and Biochemical Responses Resulting from Nitrite Accumulation in Tomato (Lycopersicon esculentum Mill. cv. Ibiza F1). Journal of Plant Physiology, 163, 1032-1039. https://doi.org/10.1016/j.jplph.2005.07.013 


\section{Abbreviations}

CL

confidence limit

Chl a

chlorophyll a

Chl b

chlorophyll b

DW

dry weight

Fd-GOGAT

ferredoxine glutamate synthase

$\mathrm{GDH}$

glutamate dehydrogenase

GS

glutamine synthetase

NADH-GOGAT NADH glutamate synthase

NR

nitrate reductase

$\mathrm{NiR}$

nitrite reductase 